\title{
OBOWIĄZEK WLADZ PUBLICZNYCH PROWADZENIA POLITYKI ZAPEWNIAJĄCEJ BEZPIECZEŃSTWO EKOLOGICZNE ROZUMIANE JAKO SYNONIM ODPOWIEDNIEJ JAKOŚCI ŚRODOWISKA
}

\begin{abstract}
Streszczenie. W artykule autorka analizuje kwestie konstytucyjnego zobowiązania władz publicznych do dbałości o jakość środowiska z uwzględnieniem troski o przyszłe pokolenia. Wskazuje, iż pojęcie bezpieczeństwa ekologicznego nie zostało przez prawodawcę sprecyzowane, a poglądy formułujące prawo do bezpieczeństwa ekologicznego uznawane są za sporne. Podkreśla, że aktualnie kluczowym wyzwaniem dla władz publicznych jest problem niskiej emisji.
\end{abstract}

Slowa kluczowe: środowisko, ochrona, bezpieczeństwo, polityka.

\section{UWAGI WSTECPNE}

„Bezpieczeństwo ekologiczne” jest terminem prawnie niezdefiniowanym, będącym częścią pojęcia ogólnego bezpieczeństwa państwa i społeczeństwa. Należy przyjąć, iż jego zapewnienie obejmuje m.in. zabezpieczenie potrzeb istnienia, przetrwania, ochrony poziomu i jakości życia. Jak trafnie zauważa Piotr Korzeniowski, w ramach instytucji prawnej bezpieczeństwa ekologicznego mamy do czynienia z przeplataniem się wzajemnych praw i obowiązków władz publicznych i obywateli (Korzeniowski 2012, 182). Pojawić się mogą jednakże wątpliwości, czy jednostka ma prawo domagania się od władz publicznych zapewnienia realizacji swego prawa do środowiska, obejmującego bezpieczeństwo ekologiczne, w szczególności w kontekście aktualnych problemów związanych z niską emisją.

\section{BEZPIECZEŃSTWO EKOLOGICZNE - PROPOZYCJE DEFINICYJNE}

Art. 74 ust. 1 Konstytucji Rzeczypospolitej Polskiej z dnia 2 kwietnia 1997 r. (Dz.U. z 1997 r. Nr 78, poz. 483 ze zm.; dalej: Konstytucja) stanowi, iż ,władze publiczne prowadzą politykę zapewniającą bezpieczeństwo ekologiczne współczesnemu i przyszłym pokoleniom”. Konstytucyjny obowiązek prowadzenia

*Narodowy Instytut Samorządu Terytorialnego w Łodzi, agnieszka.jaworowicz-rudolf@nist. gov.pl. 
takiej polityki adresowany jest do wszelkich organów oraz instytucji państwowych i samorządowych, niezależnie od miejsca zajmowanego w systemie podziału władz (Garlicki 2003, 3). Obowiązek ten nie został jednak w żaden sposób przez prawodawcę sprecyzowany, powinien być zatem rozumiany możliwie szeroko, obejmując prowadzenie wszystkich dostępnych polityk, nakierowanych na zapewnienie bezpieczeństwa ekologicznego (Bukowski 2002, 68), oraz być realizowany w oparciu o wszelkiego rodzaju działania (tak władcze, jak i organizatorsko-inspiracyjne), byle dały się one przyporządkować ogólniejszej, politycznej koncepcji (Garlicki 2003, 3). Ma on charakter interdyscyplinarny, wieloaspektowy i wymaga zaangażowania praktycznie całego aparatu państwowego. Zakres omawianego obowiązku będzie determinowany rozumieniem pojęcia bezpieczeństwa ekologicznego, które również nie jest prawnie zdefiniowane, co wydaje się być celowym zabiegiem prawodawcy, a jednocześnie daje asumpt do zgłaszania propozycji definicyjnych, w szczególności przez przedstawicieli doktryny prawa.

Zdaniem Romana Paczuskiego termin „bezpieczeństwo ekologiczne” oznacza

obowiązek podejmowania przez władze publiczne konkretnych działań mających na celu ochronę obywateli oraz ich przyszłych pokoleń przed zagrożeniami wynikającymi z niedostatecznie zharmonizowanego rozwoju gospodarczego i społecznego z wymogami ochrony środowiska (Paczuski 2005, 120-121).

Jak wskazuje Marek Pietraś, bezpieczeństwo ekologiczne obejmuje działania nakierowane na wiele dziedzin życia społecznego, gospodarczego, które mogą mieć bezpośredni lub pośredni wpływ na środowisko (Pietraś 2000, 6-50). Zdaniem P. Korzeniowskiego bezpieczeństwo ekologiczne obejmuje działanie lub zaniechanie pozwalające zachować lub przywrócić równowagę przyrodniczą, niezbędną do zapewnienia współczesnemu i przyszłym pokoleniom odpowiednich warunków życia oraz realizacji prawa do korzystania z zasobów środowiska i zachowania jego wartości. Zapewnienie bezpieczeństwa ekologicznego oznacza utrzymanie pewnego poziomu ochrony, który pozwoli na korzystanie przez człowieka z wartości środowiska i jego zasobów. Celem bezpieczeństwa ekologicznego jest określenie optymalnych warunków zdrowia ludzi przez: 1) ocenę ich narażenia na szkodliwe działanie zanieczyszczeń, 2) opracowanie zasad zapobiegania skutkom zanieczyszczeń biologicznych, chemicznych oraz fizycznych w środowisku (Korzeniowski 2012, 173-174). Anna Surówka z kolei podkreśla, iż definiując pojęcie bezpieczeństwa ekologicznego, trzeba patrzeć zawsze przez pryzmat wartości wyrażonej w art. 68 Konstytucji i należy pamiętać, że zdrowie człowieka jest konstytucyjną wartością nadrzędną w stosunku do środowiska naturalnego, dlatego wskazuje, że „Bezpieczeństwo ekologiczne służy przede wszystkim dążeniu do stworzenia środowiska bytowania człowieka wolnego od zagrożeń, które mogłyby niekorzystnie wpływać na jego zdrowie lub zagrażać jego życiu" (Surówka 2012, 155). Zbigniew Dziamski i Waldemar Nowosielski zauważają, iż podobnie rozumiał to pojęcie Włodzimierz Michajłow, który w roku 
1986 na Kongresie Intelektualistów w Warszawie zaproponował, by bezpieczeństwo ekologiczne definiować jako „kształtowanie takich stosunków przyrodniczych i społecznych w obrębie biosfery naszej planety, które zapewniłyby jej wewnętrzną równowagę w sposób gwarantujący zarazem właściwe możliwości życiowe całej ludzkości i jej dalszy bezpieczny rozwój" (Dziamski, Nowosielski 2012, 206). Michajłow kładł nacisk na ochronę życia i zdrowia ludzi w wyniku zmian ekologicznych i wskazywał, że bezpieczeństwo ekologiczne to likwidacja lub zmniejszenie do minimum zagrożeń życia i zdrowia człowieka (za Dziamski, Nowosielski 2012).

Próbę zdefiniowania pojęcia bezpieczeństwa ekologicznego podjęto także w orzecznictwie Trybunału Konstytucyjnego. W wyroku z dnia 6 czerwca 2006 r. TK przyjął, iż termin ten powinien być rozumiany jako ,uzyskanie takiego stanu środowiska, który pozwala na bezpieczne przebywanie w tym środowisku i umożliwia korzystanie z tego środowiska w sposób zapewniający rozwój człowieka" (wyr. TK z dnia 6 czerwca 2006 r., K 23/05, OTK-A 2006, nr 6, poz. 62). Podobnie w wyroku TK z 13 maja 2009 r. wskazano, że:

Bezpieczeństwo ekologiczne, które ma być zapewnione przez władze publiczne to stan środowiska pozwalający na bezpieczne przebywanie w nim i korzystanie z niego. Instrumentem zapewnienia tego bezpieczeństwa jest ochrona środowiska - chroniąc je ustawodawca winien kierować się zasadą zrównoważonego rozwoju (Kp 2/09, OTK ZU nr 5A/09, poz. 66).

Podsumowując, można przyjąć, iż dla ustalenia znaczenia „bezpieczeństwa ekologicznego" w ujęciu prawnym konieczne jest odwołanie się do regulacji konstytucyjnych związanych z ochroną środowiska, w szczególności do art. 5, art. 68 oraz pozostałych ustępów art. 74 Konstytucji. Ochrona środowiska jest jedną $\mathrm{z}$ form zagwarantowania bezpieczeństwa ekologicznego. Pojęcie bezpieczeństwa ekologicznego jest jednakże szersze niż ochrona środowiska. Bezpieczeństwo ekologiczne w ujęciu konstytucyjnym jest synonimem odpowiedniej jakości środowiska, w związku z czym władze publiczne są zobowiązane do jej zapewnienia odpowiednio do potrzeb zarówno współczesnego społeczeństwa, jak i przyszłych pokoleń. W ramach prowadzenia polityki gwarantującej bezpieczeństwo ekologiczne organy władzy publicznej mają obowiązek ochrony środowiska, co zostało podkreślone w art. 74 ust. 2 Konstytucji.

\section{PRAWO DO BEZPIECZEŃSTWA EKOLOGICZNEGO?}

W ocenie P. Korzeniowskiego z przepisów Konstytucji wynika, że każdy ma prawo do bezpieczeństwa ekologicznego. Jest to jedno z podstawowych praw człowieka (Korzeniowski 2012, 174). Podobny wniosek sformułowała A. Surówka (Surówka 2012, 162). Za wyznaczeniem konstytucyjnego prawa do korzystania ze środowiska opowiedziała się również Anna Haładyj. Jej zdaniem należy 
jednoznacznie stwierdzić, że przywołane przepisy Konstytucji ustanawiają obywatelskie prawo do środowiska, którego treść wyprowadzić można z art. 5, 68 ust. 4, art. 74 oraz art. 86, prawo podmiotowe zaś, wyrażone w art. 74 ust. 3, jest gwarancją jego realizacji (Haładyj 2002, 37). Ja także we wcześniejszych publikacjach wskazywałam, iż prawo do korzystania ze środowiska należytej jakości jest kluczowym czynnikiem warunkującym urzeczywistnienie zrównoważonego rozwoju (Jaworowicz-Rudolf 2010, 69-72) i w mej ocenie człowiek ma prawo do należytej jakości środowiska, nawet mimo braku stosownych regulacji prawnych w danym porządku prawnym expressis verbis takie prawo przewidujących, a władza publiczna ma starać się zapewniać właściwy stan środowiska, by prawo to mogło być wykonywane (Jaworowicz-Rudolf 2013, 586). Należy zauważyć, że choć prawo jednostki do środowiska należytej jakości nie zostało także wyraźnie sformułowane w treści ratyfikowanej przez Polskę Konwencji o Ochronie Praw Człowieka i Podstawowych Wolności z dnia 4 listopada 1950 (Dz.U. z 1993 r. Nr 61, poz. 284 ze zm.; dalej: Konwencja) ${ }^{1}$, to jednak Europejski Trybunał Praw Człowieka w Strasburgu, stosując twórczą wykładnię Konwencji, prawo takie dowodzi pośrednio, co umożliwia mu merytoryczne rozpoznawanie indywidualnych skarg w sprawach dotyczących odpowiedzialności władz publicznych za stan środowiska w zakresie, $w$ jakim naruszenie środowiska godzi jednocześnie w sferę podstawowych praw człowieka uznanych przez Konwencję. Z linii orzeczniczej Trybunału w Strasburgu wynika, że jakość środowiska może być chroniona za pośrednictwem gwarancji poszanowania życia prywatnego, życia rodzinnego, miru domowego, a także w ramach ochrony prawa do życia ${ }^{2}$. W sprawie Hamer przeciwko Belgii ETPC w 2007 r. stwierdził po raz pierwszy, że środowisko - nie będąc explicite chronione przez Konwencję - jest wartością samą w sobie, leżącą w interesie zarówno społeczeństwa, jak i władz publicznych. Trybunał uznał, że władze publiczne są zobowiązane do działania na rzecz ochrony środowiska, a względy gospodarcze, nawet prawo własności, nie powinny mieć pierwszeństwa przed względami ochrony środowiska, w szczególności, gdy państwo wprowadziło na tym polu przepisy prawne ${ }^{3}$. Na marginesie można zasygnalizować, iż na mocy traktatu lizbońskiego skuteczność ma również inny dokument międzynarodowy - Karta Praw Podstawowych Unii Europejskiej, który w rozdziale

\footnotetext{
${ }^{1}$ Ratyfikowana przez Polskę w dniu 15 grudnia $1992 \mathrm{r}$.

${ }^{2} \mathrm{~W}$ postępowaniach przed ETPC zapadło wiele wyroków nakazujących różnym krajom wypłacenie odszkodowania za brak dostatecznej ochrony środowiska. Należne od państwa odszkodowania są determinowane wysokością szkody. Szerzej nt. prawa do środowiska w świetle wykładni i wybranego orzecznictwa Trybunału Praw Człowieka zob. Jaworowicz-Rudolf (2013, 567-575). Zob. także: sprawy Kyrtatos przeciwko Grecji (skarga nr 41666/98); Giacomelli przeciwko Włochom (skarga nr 59909/00), https://bip.ms.gov.pl/pl/prawa-czlowieka/ [dostęp 15.07.2018].

${ }^{3}$ Hamer przeciwko Belgii (skarga nr 21861/03), Izba (Sekcja II), zob. § 79 wyroku. Jak zaznaczyłam, Konwencja chroni prawa jednostki, a nie prawa kolektywne, i w jej świetle można mówić jedynie o indywidualnym prawie do ochrony środowiska albo raczej o prawie skarżącego do ochrony jego środowiska. Zob. Rakoczy (2007, 9-10).
} 
IV Solidarność w art. 37 „Ochrona środowiska” przewiduje, że wysoki poziom ochrony środowiska i poprawa jego jakości muszą być zintegrowane z politykami Unii i zapewnione zgodnie z zasadą zrównoważonego rozwoju (Dz.Urz. UE C 202/389 z 7.06.2016) ${ }^{4}$. Ta norma prawna Karty stanowi swoiste novum w obszarze ochrony praw człowieka i obywatela, jest to nowa kategoria praw, niemających waloru powszechności, które stopniowo są wprowadzane do szerszego systemu ochrony praw człowieka, co urzeczywistnia postęp w tej dziedzinie.

Poglądy formułujące prawo do bezpieczeństwa ekologicznego na gruncie polskiego porządku prawnego uznawane są w doktrynie za sporne. Wydaje się, że większość przedstawicieli doktryny stoi jednak na stanowisku, iż z obowiązków określonych art. 74 ust. 1 Konstytucji nie da się wyprowadzić żadnych praw podmiotowych ${ }^{5}$, a naruszenie tego obowiązku nie wiąże się z żadną sankcją (Banaszak 2012, 438; Garlicki 2003, 2). Zdaniem Lecha Garlickiego sformułowanie wyrażone w art. 74 ust. 1 Konstytucji RP ma charakter typowy dla określania zadań (zasad polityki) państwa, nie rodzi natomiast bezpośrednio jakichkolwiek praw podmiotowych po stronie jednostki. Jak wskazują Stanisław Bułajewski i Marcin Dąbrowski, przepis art. 74 ma budowę typową dla przepisów o charakterze programowym. Wyznacza on zadania i cele polityczne wszystkim organom władzy publicznej, równocześnie nie czyniąc żadnego z nich bezpośrednio zobowiązanym. W związku z powyższym nie można z niego wyinterpretować żadnych praw podmiotowych i nie może on stanowić podstawy indywidualnych roszczeń jednostki wobec władz państwowych i samorządowych (Bułajewski, Dąbrowski 2008, 191-192). Obowiązek prowadzenia polityki zapewniającej bezpieczeństwo ekologiczne organy władzy będą realizowały przez powstrzymanie się od wydawania aktów stanowienia i stosowania prawa, które mogłyby zagrozić środowisku i bezpieczeństwu ekologicznemu oraz wydawania takich aktów, które sprzyjałyby realizacji i ochronie tych wartości. Zdaniem wymienionych autorów, o ile trudno, na podstawie art. 74 ust. 1, byłoby zmusić organy władzy państwowej do wydania aktu prawnego (aktu stosowania lub stanowienia prawa), o tyle możliwe byłoby jednak kwestionowanie ustanowionego aktu, który sprzeciwia się założeniom niniejszej regulacji. Również Bartosz Rakoczy stwierdza, że obowiązek wyrażony w art. 74 ust. 1 Konstytucji ma charakter bardziej deklaracji politycznej państwa niż normy prawnej. Zaznacza, że polski ustawodawca pominął zupełnie kwestie znaczenia wyraźnego sformułowania konstytucyjnego prawa do środowiska, a brak bezpośredniego sformułowania takiego prawa ma duże znaczenie w procesie stosowania prawa (Rakoczy 2006, 199, 206, 247). Wojciech Jakimowicz zauważa, że art. 74 Konstytucji, w przeciwieństwie do art. 68 ust. 1, nie zawiera zwrotu ,prawo do”, co nie pozwala skorelować obowiązku wyrażonego

${ }^{4}$ Zob. http://eur-lex.europa.eu/legal-content/PL/TXT/?uri=CELEX\%3A12012P\%2FTXT [dostęp 15.07.2018]. Szerzej zob. Wróblewski (2015, 17-23).

${ }^{5}$ Szerzej nt. refleksji filozoficznych nad prawami podmiotowymi, różnic w polskim i angielskim dyskursie nt. praw podmiotowych zob. Raburski (2017). 
w art. 74 ust. $1 \mathrm{z}$ jakimkolwiek prawem podmiotowym, czy nawet prawem socjalnym. W związku z tym tylko w gestii ustawodawcy leży doprecyzowanie, w jaki sposób i w jakiej formie będzie realizował obowiązek zapewnienia bezpieczeństwa ekologicznego (Jakimowicz 1999, 38). Przesądza o tym treść art. 81 Konstytucji, zgodnie z którym praw wynikających z art. 74 można dochodzić w granicach określonych ustawą. Konkretyzacja omawianego obowiązku następować będzie we wszystkich ustawach składających się na materialne prawo ochrony środowiska oraz przepisów ustrojowych dotyczących poszczególnych władz publicznych (Bukowski 2002, 70).

\section{PROBLEM NISKIEJ EMISJI - KLUCZOWE WYZWANIE DLA WSPÓŁCZESNYCH WLADZ PUBLICZNYCH W ŚWIETLE OBOWIĄZKU ZAPEWNIENIA BEZPIECZEŃSTWA EKOLOGICZNEGO}

Można dywagować, czy biorąc pod uwagę kryterium obowiązków danego organu na szczeblu zarówno państwowym, jak i terytorialnym oraz zakres podejmowanych przez niego działań w kierunku ograniczenia negatywnych zmian w środowisku, a szerzej: obowiązku zapewnienia bezpieczeństwa ekologicznego, zasadnym jest na gruncie prawa polskiego rozważanie złożenia pozwu przeciwko władzy państwowej albo samorządowej z tytułu dopuszczenia się zaniedbań w tym obszarze. Obecnie, z uwagi na występowanie tzw. sytuacji smogowych, kwestia ta nabiera żywotnego znaczenia praktycznego i rozgłosu medialnego, zwłaszcza na skutek prężnego działania ruchów obywatelskich zrzeszonych w ramach inicjatywy Polski Alarm Smogowy oraz innych stowarzyszeń proekologicznych, zatroskanych złą jakością powietrza w Polsce, których przedstawiciele sugerują obywatelom masowe wnoszenie pozwów do sądu z żądaniem „odszkodowania za skażone powietrze”, czy „zadośćuczynienia za smog”. Podnoszą oni argument, iż prawa obywatelskie, np. do ochrony zdrowia, do wypoczynku, swobody przemieszczania się, mogą być realizowane tylko wtedy, gdy państwo zapewnia prawidłową ochronę środowiska. Podkreślają, że każdy Polak ma zagwarantowane w Konstytucji w szczególności prawo do ochrony zdrowia i do obowiązków rządzących należy zapewnianie dostępu do nieskażonego powietrza. Argumentują też, iż skoro, zgodnie z art. 7 ust. 1 pkt 1 ustawy z dnia 8 marca 1990 r. o samorządzie gminnym (tekst jedn. Dz.U. z 2019 r., poz. 506), do obowiązków gmin należy ochrona środowiska i przyrody, to powstaje zgoła racjonalne pytanie, w zakresie odpowiedzialności tego podmiotu, co efektywnego gmina zrobiła, aby wyeliminować obecny stan, czy też - jak usprawiedliwić brak odpowiednich uchwał samorządowych w sprawie wymiany pieców grzewczych. W mojej ocenie istnieje duże ryzyko, że krajowy sąd takich roszczeń odszkodowawczych raczej nie uzna, a biorąc pod uwagę dotychczasowe orzecznictwo wątpliwe jest też, by sprawę pozytywnie rozpatrzył ETPC w Strasburgu, do którego 
należałoby zaskarżyć państwo polskie. Z pewnością rozstrzygnięcie takiej sprawy miałoby charakter precedensowy.

Warto jednocześnie zaznaczyć, iż w Polsce obywatele podjęli próby dochodzenia na drodze sądowej roszczeń przeciwko władzy publicznej z tytułu zaniedbań w przedmiocie ochrony środowiska w oparciu o regulacje cywilistyczne (naruszenie dóbr osobistych). W czerwcu 2013 r. Sąd Okręgowy w Gliwicach (Ośrodek Zamiejscowy w Rybniku) oddalił pierwszy w Polsce pozew wniesiony z powództwa cywilnego przez jednego mieszkańców Rybnika, Zdzisława Kuczmę, znanego na Śląsku działacza ze stowarzyszenia Rybnicki Alarm Smogowy, przeciwko Skarbowi Państwa, reprezentowanemu przez Ministra Środowiska, w którym powód domagał się wypłacenia 10 tys. zł zadośćuczynienia za smog nad miastem spowodowany tzw. niską emisją (wyr. Sądu Okręgowego w Gliwicach z dnia 6 czerwca 2013 r., II C 20/13). W pozwie zarzucono naruszenie dóbr osobistych, domagano się zadośćuczynienia oraz złożono żądanie postulatywne zobowiązania pozwanego do podjęcia działań legislacyjnych: złożenia projektów odpowiednich aktów normatywnych, mających na celu wprowadzenie do porządku prawnego w terminie do dnia 30 czerwca 2014 r. obowiązku sprzedaży wszelkich kotłów przeznaczonych do ogrzewania gospodarstw domowych, bez względu na moc kotła, certyfikatów zapewniających przestrzeganie norm emisyjnych w zakresie emisji pyłów (2,5-10), zgodnie z Dyrektywą Parlamentu Europejskiego i Rady nr 2008/50/ WE z dnia 21 maja 2008 r. w sprawie jakości powietrza i czystszego powietrza dla Europy, zw. Dyrektywą Clean Air For Europe - CAFE (Dz.Urz. UE L 152 z 11.06.2008, s. 1-44) ; w prowadzenia norm dla paliw stałych stosowanych na potrzeby ogrzewania gospodarstw domowych; wprowadzenia zakazu stosowania paliw stałych nieodpowiadających normom, zgodnie z ww. dyrektywą z zagrożeniem sankcją za nieprzestrzeganie norm o charakterze odstraszającym. W uzasadnieniu pozwu zawarto stwierdzenie, że smog źle wpływa na zdrowie powoda. Wskazano też, że państwo polskie dopuściło się wielu zaniedbań, a czynione działania proekologiczne nazwano pozornymi. Sąd przyznał, że choć problem zanieczyszczenia powietrza w Rybniku jest bardzo duży, to jednak w jego ocenie tak sformułowane żądania, mimo występującego problemu, nie zasługiwały na uwzględnienie. Sąd uznał, że powód nie może udowodnić, iż smog źle wpływa na jego zdrowie. Sąd dodał też, że dyrektywa unijna obligująca państwo polskie do przestrzegania norm czystości powietrza, na którą powoływał się powód, ma ogólny charakter i nie można jej traktować jako prawa osobistego. W uzasadnieniu stanowiska sądu wskazano, iż uwzględnienie powództwa $\mathrm{w}$ takim zakresie stanowiłoby niedopuszczalną ingerencję we władzę ustawodawczą czy wykonawczą oraz że w powyższej sprawie nie można też mówić o zachowaniu polegającym na naruszeniu dóbr

${ }^{6}$ Zob. https:/eur-lex.europa.eu/legal-content/PL/TXT/?uri=CELEX\%3A32008L0050 [dostęp 15.07.2018]. 
osobistych. Wyrok został przez powoda zaskarżony, aczkolwiek Sąd Apelacyjny w Katowicach wyrokiem z dnia 23 stycznia 2014 r. oddalił apelację (VACa $649 / 13)^{7}$. W orzeczeniu tym podkreślono m.in., że nie jest tak, by państwo nie ponosiło odpowiedzialności za nieprzestrzeganie unijnego prawa na skutek nieimplementowania dyrektyw, jednakże odpowiedzialność taką ponosi wobec instytucji unijnych. Obowiązujące przepisy zarówno prawa polskiego, jak i unijnego nie dają natomiast prawa obywatelowi do dochodzenia w przypadku nieimplementowania przez państwo dyrektywy żądań tak określonych, jak sformułował je powód.

W 2015 r. w Sądzie Rejonowym w Rybniku został złożony kolejny pozew przeciwko Skarbowi Państwa (sygn. akt II C 1259/15) ${ }^{8}$, w którym inny działacz Rybnickiego Alarmu Smogowego domaga się od Skarbu Państwa 50 tys. zł zadośćuczynienia. Zdaniem powoda zanieczyszczenie powietrza w Rybniku godzi

${ }^{7}$ Można na marginesie nadmienić, iż ten sam obywatel w 2015 r. zaskarżył do Wojewódzkiego Sądu Administracyjnego w Gliwicach uchwałę Rady Miasta Wisła z dnia 27 maja 2008 r. nr XX/259/2008 w przedmiocie opłaty miejscowej, podnosząc m.in., że samorząd Wisły pobiera niezgodnie z prawem opłatę miejscową (potocznie określaną taksą klimatyczną), i sprawę tę wygrał. WSA stwierdził nieważność zaskarżonej uchwały w całości. Zob. wyr. WSA w Gliwicach z dnia 24 listopada 2015 r., I SA/Gl 370/15, http://orzeczenia.nsa.gov.pl/doc/5986875EEA [dostęp 15.07.2018]. Moim zdaniem można by przyjąć, iż to nie jest wyrok w sprawie samej opłaty, lecz pośrednio dotyczący prawa obywateli do czystego powietrza, gdyż pokazuje, że władze publiczne nie mogą dłużej ignorować problemu jego jakości.

${ }^{8}$ Sprawa z powództwa Oliwera Palarza nie została jeszcze zakończona, ale zyskała dość szeroki rozgłos medialny. Powód zaznaczył, że powództwo jest wynikiem współpracy Alarmu Smogowego m.in. z Fundacją Frank Bold, organizacją pozarządową, która jako członek Justice and Environment (J\&E) wchodzi w skład Visegrad 4 Aarhus Center (V4 AC). V4 AC udziela porad prawnych oraz wsparcia mieszkańcom krajów Grupy Wyszehradzkiej (Visegrad 4 Region) w kwestii udziału społeczeństwa w sprawach dotyczących środowiska. Prawnicy fundacji sporządzili w tej sprawie pozew oraz zapewnili powodowi nieodpłatną obsługę prawną. Zob. http://frankbold. pl/ [dostęp 15.07.2018]. Alarm Smogowy współpracuje także z Fundacją ClientEarth Prawnicy dla Ziemi. ClientEarth jest jedną z wiodących organizacji pozarządowych zajmujących się prawem ochrony środowiska w Unii Europejskiej, zarejestrowaną według prawa Wielkiej Brytanii oraz fundacją zarejestrowaną w Polsce jako Fundacja ClientEarth Prawnicy dla Ziemi. 29 kwietnia 2015 r. brytyjski Sąd Najwyższy przyznał rację ClientEarth w sporze sądowym toczonym przeciwko rządowi Wielkiej Brytanii - The Supreme Court, R (on the application of ClientEarth) (Appellant) $\mathrm{v}$ Secretary of State for the Environment, Food and Rural Affairs (Respondent) - The Supreme Court, https://www.supremecourt.uk/cases/uksc-2012-0179.html [dostęp 15.07.2018], w którym organizacja zarzuciła rządowi naruszenie art. 13, 22 i 23 Dyrektywy Parlamentu Europejskiego i Rady 2008/50/WE z dnia 21 maja 2008 r. w sprawie jakości powietrza i czystszego powietrza dla Europy. Wyrokiem sądu rząd brytyjski został zobligowany do przyjęcia do 31 grudnia 2015 r. nowych planów ochrony powietrza, służących zmniejszeniu przekroczeń stężeń szkodliwych tlenków azotu w najkrótszym możliwym czasie. W Polsce ClientEarth m.in. angażuje się w procesy legislacyjne, przygotowuje opinie i raporty prawne, monitoruje przestrzeganie prawa przy wydawaniu decyzji środowiskowych dla inwestycji oraz uczestniczy w postępowaniach administracyjnych i sądowych w kwestiach środowiskowych lub je prowadzi. Zob. https://www.pl.clientearth.org/ [dostęp 15.07.2018]. 
w jego dobra osobiste, takie jak zdrowie i komfort życia ${ }^{9}$. Jako podstawy prawne umożliwiające złożenie pozwu powód wymienił art. 23 ustawy z dnia 23 kwietnia 1964 r. - Kodeks cywilny (prawo do ochrony życia prywatnego i mieszkania; tekst jedn. Dz.U. z 2018 r., poz. 1025 ze zm.). Powołano się również na art. 8 ratyfikowanej Konwencji o Ochronie Praw Człowieka i Podstawowych Wolności. Jego zdaniem na gruncie tego przepisu orzecznictwo Europejskiego Trybunału Praw Człowieka potwierdza, że życie na obszarze, na którym występuje skażenie powietrza w przypadku pasywności lub nieefektywności działań władz publicznych zobowiązanych do podjęcia określonych działań, stanowi naruszenie art. 8 Konwencji. Powód podkreślił, iż pozew ma być sygnałem dla władz państwowych, że społeczeństwo nie zamierza biernie znosić dalszej bezczynności w zakresie poprawy jakości powietrza i jeśli wygra sprawę, uzyskując zadośćuczynienie, chce całą kwotę przekazać na cele dobroczynne: na szpital bądź hospicjum zajmujące się leczeniem chorób spowodowanych złą jakością powietrza.

Przedstawiciele ekologicznych organizacji pozarządowych byli również inicjatorami wniesionej przeciwko Polsce skargi do Komisji Europejskiej ws. fatalnej jakości powietrza w Polsce (warto odnotować, że pod skargą podpisało się ponad 23 tys. osób). Autorzy skargi zarzucili władzom publicznym wieloletnie zaniedbania, które doprowadziły do tego, że w wielu miejscach w Polsce jakość powietrza jest bardzo zła, a stężenie szkodliwych pyłów przekracza normy o nawet kilka tysięcy procent. Zwrócono także uwagę, iż w Polsce nie są respektowane dyrektywy regulujące poziomy zanieczyszczenia w aglomeracjach. Komisja wniosła na Polskę skargę do Trybunału Sprawiedliwości UE w Luksemburguº,

\footnotetext{
${ }^{9}$ Powód argumentował, że zanieczyszczenie powietrza w Rybniku w latach 2010-2015 regularnie przekraczało normy dopuszczalne m.in. dla pyłów PM10, PM2,5 i benzo(a)pirenu, a jako dowód przedstawił raporty dzienne, miesięczne i roczne, zawierające wyniki pomiarów składu powietrza wykonane przez Wojewódzki Inspektorat Ochrony Środowiska w Katowicach. Podkreślał, że mieszkanie w mieście, w którym systematycznie dochodzi do przekroczeń dopuszczalnych stężeń szkodliwych substancji, oznacza wiele negatywnych konsekwencji, m.in. dyskomfort psychiczny, poważne obawy o zdrowie związane ze zwiększonym ryzykiem zachorowania na astmę czy przewlekłą obturacyjną chorobę płuc, a ponadto znaczne zanieczyszczenie powietrza ogranicza też swobodę poruszania się, bo w takiej sytuacji zalecane jest pozostanie w domu.

${ }^{10}$ Komisja Europejska już wcześniej miała zastrzeżenia do prowadzenia przez Polskę działań na rzecz poprawy jakości powietrza. W 2008 r. udzieliła Polsce ostrzeżenia, w którym stwierdziła, że z uwagi na zgłoszone przekroczenia dopuszczalnych wartości stężenia pyłu PM10 w przypadku nieprzedłożenia stosownych wyjaśnień ma zamiar wszcząć postępowanie w sprawie naruszenia przepisów na mocy art. 226 traktatu (obecnie art. 258 Traktatu o funkcjonowaniu Unii Europejskiej). Polska wysłała odpowiedź na zarzuty i wyjaśnienia, a Komisja Europejska wezwała nasz kraj do usunięcia uchybień w związku z przekroczeniami poziomów dopuszczalnych pyłu PM10 na obszarze województwa śląskiego. Następny epizod miał miejsce 31 stycznia 2012 r., kiedy to Komisja Europejska skierowała skargę do Trybunału Sprawiedliwości Unii Europejskiej, w której zarzucono Polsce nieprzyjęcie do krajowego porządku prawnego i niewprowadzenie w życie wszystkich niezbędnych przepisów, wymaganych przez Dyrektywę CAFE. Wraz ze skargą KE wnioskowała o nałożenie na Polskę kary wysokości 71 521,38 EUR dziennie (naliczanej
} 
który w lutym 2018 r. uznał, że nasze państwo naruszyło unijne przepisy dotyczące jakości powietrza (wyr. w sprawie C-336/16 Komisja/Polska) ${ }^{11}$. Uznano, że nasz kraj nie wypełnił zobowiązań odnoszących się do przestrzegania rocznych i dziennych dopuszczalnych wartości związanych $\mathrm{z}$ istnieniem w powietrzu pyłu zawieszonego (PM10), a także przygotowania planów, które pozwolą skrócić liczbę dni z przekroczeniami ${ }^{12}$. W uzasadnieniu TSUE stwierdził, iż sam fakt przekroczenia dopuszczalnych wartości stężenia PM10 w otaczającym powietrzu wystarczy do stwierdzenia uchybienia zobowiązaniom państwa członkowskiego. Stwierdzono, że okresy przewidziane na poprawę jakości powietrza w polskich programach ochrony powietrza są zbyt długie ${ }^{13}$. Taki wyrok oznacza, że sędziowie

aż do usunięcia uchybień). Rok później KE wycofała skargę, a sprawa została wykreślona z rejestru Trybunału Sprawiedliwości UE, ponieważ Polska dokonała zmian w prawie krajowym i przesłała informację o dokonaniu prawidłowej transpozycji dyrektywy. Niestety, transpozycja dyrektywy nie sprawiła, że powietrze w Polsce uległo istotnej poprawie, a przekroczenia obowiązujących norm nie mają już miejsca. Co więcej, dyrektywa nie została transponowana prawidłowo. W związku z tym w grudniu 2015 r. Komisja Europejska wniosła nową skargę do Trybunału Sprawiedliwości UE.

${ }^{11}$ Zob. https://curia.europa.eu/jcms/upload/docs/application/pdf/2018-02/cp180019pl.pdf [dostęp 15.07.2018].

${ }^{12}$ Podobny wyrok zapadł wcześniej w sprawie przeciwko Bułgarii (Komisja Europejska przeciwko Republice Bułgarii, nr sprawy C-488/15). Komisja Europejska pozwała Bułgarię do Trybunału Sprawiedliwości UE 14 września 2015 r., a 5 kwietnia 2017 r. Trybunał Sprawiedliwości UE ogłosił wyrok w sprawie naruszenia przepisów tzw. Dyrektywy CAFE (zob. InfoCuria - Orzecznictwo Trybunału Sprawiedliwości CLI:EU:C:2017:267). Trybunał uznał, że Republika Bułgarii nie wypełniała postanowień dotyczących dopuszczalnych stężeń zanieczyszczeń pyłowych oraz nie przygotowała odpowiednich planów naprawczych. Stwierdzono, że Republika Bułgarii nie wypełniła zobowiązań określonych w art. 13 ust. 1, odnoszących się do przestrzegania rocznych i dziennych dopuszczalnych wartości związanych z istnieniem w powietrzu pyłu zawieszonego (PM10) oraz naruszyła w art. 23 ust. 1 akapit drugi dyrektywy w związku ze zobowiązaniem do przygotowania planów jakości powietrza tak, aby okres powyższych przekroczeń był możliwie jak najkrótszy. Trybunał orzekł, że Bułgaria od 2007 r. co najmniej do 2014 r. systematycznie nie przestrzegała dziennych i rocznych dopuszczalnych wartości stężeń pyłu zawieszonego w powietrzu PM10. Sędziowie uznali, że Bułgaria nie zdołała wykazać, iż pomimo trwałego przekroczenia wartości dopuszczalnych podjęła niezbędne działania, aby przekroczenia trwały jak najkrócej. Polska wspierała Bułgarię w tej sprawie, występując w charakterze tzw. interwenienta przed Trybunałem. Zob. http://curia.europa.eu/juris/liste.jsf?num=C-488/15\&language=PL oraz http://curia. europa.eu/juris/celex.jsf?celex=62015CJ0488\&lang1 $=$ pl\&type $=$ TXT\&ancre $=[$ dostęp 15.07.2018] Warto dodać, że oprócz Polski i Bułgarii jeszcze dziewięć innych krajów, które przekroczyły limity PM10 i dwutlenku azotu (NO2), aby uniknąć pozwu w ETS zostało wezwanych do przedstawienia danych, mających przekonać Komisję, że podejmują wystarczające kroki w celu zmniejszenia zanieczyszczenia.

${ }^{13}$ Obowiązek sporządzania planów dotyczących jakości powietrza w przypadku przekroczenia wartości dopuszczalnych dla stężenia PM10 w otaczającym powietrzu ciąży na Polsce od dnia 11 czerwca $2010 \mathrm{r}$. W przyjętych później planach upływ terminów przewidzianych na położenie kresu tym przekroczeniom został ustalony, w zależności od konkretnej strefy, na czas między 2020 r. a 2024 r. Polska utrzymywała, że terminy te są w pełni dostosowane do skali przekształceń strukturalnych niezbędnych do położenia kresu przekroczeniom i zwracała w szczególności uwage 
uznali podejmowane przez polskie rządy działania na rzecz poprawy jakości powietrza za niewystarczające ${ }^{14}$.

Powyższy wyrok Trybunału Sprawiedliwości należy traktować jako ostrzeżenie dla władzy publicznej, by jak najszybciej podjęła zdecydowane działania w celu poprawienia jakości powietrza i że raczej krytycznie oceniono to, co zrobiono do tej pory. Większość działań w ramach Programu „Czyste powietrze” (zadań wynikających z przyjętych w dniu 25 kwietnia 2017 r. przez Radę Ministrów rekomendacji Komitetu Ekonomicznego Rady Ministrów - tzw. Program pt. „Czyste powietrze") jest bowiem prowadzona zbyt wolno ${ }^{15}$. Zdaniem Ministerstwa Środowiska, program jest priorytetowy i sukcesywnie wdrażany. Od lutego $2018 \mathrm{r}$. realizowany jest rządowy program SmogStop, mający na celu zmniejszenie zanieczyszczeń, a jednocześnie zwiększenie możliwości ocieplania domów, zwłaszcza tam, gdzie powietrze nie jest czyste, przewidujący m.in. dotacje na termomodernizację domów jednorodzinnych i mieszkań. Należy jednak zauważyć, że program ten ma objąć jedynie 23 z 33 miejscowości, które znalazły się na przygotowanej przez Światową Organizację Zdrowia liście najbardziej zanieczyszczonych miast w Europie ${ }^{16}$, a konieczne jest wdrożenie szeroko zakrojonego programu walki z ubóstwem energetycznym i termomodernizacji.

na trudności o charakterze społeczno-gospodarczym i budżetowym związane z potrzebą realizacji znacznych inwestycji technicznych.

${ }^{14}$ Rozstrzygnięcie to nie pociąga za sobą automatycznego poniesienia finansowych konsekwencji przez nasz kraj, ponieważ Polsce przysługuje jeszcze dwuletni okres na poprawę sytuacji i dostosowanie do prawa unijnego w zakresie ochrony powietrza. Polska powinna jednak jak najszybciej podjąć działania zmierzające do poprawy jakości powietrza w kraju - w przeciwnym wypadku Komisja Europejska może domagać się sankcji finansowych. Według szacunków NIK Polsce grożą nawet 4 mld złotych kary oraz dodatkowe dziesiątki tysięcy euro za każdy dzień zwłoki. Z kolei fundacja ClientEarth szacuje, że kara może wynieść od 5 tys. do prawie 304 tys. EUR za każdy dzień naruszenia unijnych przepisów, czyli od 4,3 mln do ponad $50 \mathrm{mln}$ EUR.

${ }^{15}$ Postępy w realizacji rządowego programu walki ze smogiem można sprawdzić na stronach: http://www.polskabezsmogu.pl [dostęp 15.07.2018], https://www.mos.gov.pl/fileadmin/user_upload/mos/Aktualnosci/2018/styczen_2018/Informacja_nt._stanu_zaawansowania_prac_nad_rekomendacjami_-_Program_Czyste_Powietrze.pdf [dostęp 15.07.2018]. Niestety z jego 15 punktów dotychczas zrealizowano niewiele, w szczególności w dniu 1 sierpnia 2017 r. zostało wydane przez Ministra Rozwoju i Finansów rozporządzenie w sprawie kotłów na paliwo stałe (Dz.U. z 2017 r., poz. 1690). Przewiduje ono, że kotły grzewcze, które zostały wyprodukowane do 1 października 2017 r., będzie można wprowadzać do obrotu i do użytkowania do końca czerwca 2018 r. Od lipca 2018 r. w Polsce nie będzie można produkować ani instalować pieców o emisyjności niższej niż piąta klasa. W kotłach nie będzie można też instalować rusztów awaryjnych, które najczęściej służą do spalania odpadów komunalnych.

${ }^{16}$ Według raportu Światowej Organizacji Zdrowia (WHO) na 50 europejskich miast najbardziej zanieczyszczonych smogiem aż 33 są w Polsce. W pierwszej piątce znajdują się Żywiec, Pszczyna, Rybnik i Wodzisław Śląski. Program StopSmog wyklucza natomiast ze wsparcia setki miejscowości, które borykają się z zanieczyszczeniem powietrza, a nie znalazły się na liście WHO, ponieważ nie posiadają oficjalnego systemu monitoringu powietrza lub stacje monitoringu pojawiły się tam już po stworzeniu rankingu. Takie zawężenie pomocy jest zrozumiałe z uwagi na znaczące 


\section{KONKLUZJE}

Na podstawie art. 74 ust. 1 Konstytucji RP władze publiczne zostały zobowiązane do dbałości o jakość środowiska z uwzględnieniem dobra przyszłych pokoleń. Dbałość ta obejmuje wszystkie sfery działań władz publicznych i powinna być realizowana instrumentami prawnymi, ekonomicznymi, środkami technicznymi, a także poprzez prowadzenie odpowiedniej polityki edukacyjnej, przyczyniającej się do wzrostu wiedzy społeczeństwa w sprawach związanych $\mathrm{z}$ bezpieczeństwem ekologicznym. Obowiązek ten powinien być realizowany na wszystkich szczeblach administracyjnych. Ponadto środowisko jako dobro wspólne niewątpliwie powinno być płaszczyzną współdziałania władz publicznych i jednostek w celu podejmowania działań ochronnych. Należy bowiem podkreślić, iż oprócz obowiązków narzuconych władzom publicznym Konstytucja RP w art. 86 nakłada na każdego powszechny obowiązek dbałości o stan środowiska.

Jak wspomniałam, poglądy formułujące prawo do bezpieczeństwa ekologicznego uznawane są w doktrynie za sporne. Wątpliwości w tej kwestii zgłaszają konstytucjonaliści, administratywiści oraz cywiliści. Dochodzenie roszczeń związanych z prawem do życia w należytej jakości środowisku w ramach cywilnoprawnych środków ochrony prawnej zakwestionowano w dotychczasowym, przywołanym w niniejszej publikacji orzecznictwie sądowym. Należy jednak podkreślić, że obywatel nie jest pozbawiony wpływu na zainicjowanie procesu legislacyjnego w kwestiach środowiskowych, a szerzej - realizacji polityki zapewniającej bezpieczeństwo ekologiczne, czy polityki ekologicznej, ponieważ stosownie do art. 118 ust. 2 Konstytucji Rzeczypospolitej Polskiej inicjatywa ustawodawcza przysługuje również grupie co najmniej 100000 obywateli, mających prawo wybierania do Sejmu, a szczegóły tego uprawnienia precyzuje ustawa z dnia 24 czerwca 1999 r. o wykonywaniu inicjatywy ustawodawczej przez obywateli (Dz.U. z 1999 r. Nr 62, poz. 688 ze zm.). Nie jest też tak, żeby władza publiczna nie ponosiła odpowiedzialności za nieprzestrzeganie unijnego prawa, z którego można starać się wyinterpretować obowiązek podjęcia przez władzę konkretnych działań, mających na celu zapewnienie bezpieczeństwa ekologicznego, jednakże odpowiedzialność taką ponosi wobec instytucji unijnych. Można ubolewać, że sygnały o potrzebie poprawy jakości powietrza w Polsce, niewątpliwie jednego z kluczowych elementów środowiska warunkującego bezpieczeństwo ekologiczne

koszty realizacji programu (rząd zapowiedział przeznaczenie na program $750 \mathrm{mln}$ zł w ciągu kilku najbliższych lat), ale jest to rozwiązanie mało efektywne, gdyż usunięcie źródeł emisji w niektórych tylko miejscowościach nie wystarczy, aby skutecznie rozwiązać problem zanieczyszczenia powietrza w skali kraju. Zanieczyszczenia będą bowiem napływać do nich z okolicznych gmin oraz innych miast, a nawet $z$ sąsiednich województw. Należałoby zatem postulować jak najszybsze stworzenie ogólnopolskiego programu wspierającego wymianę źródeł ciepła oraz termomodernizację domów. Potrzebne są systemowe rozwiązania i działania prowadzone równolegle w kilku obszarach. 
współczesnemu i przyszłym pokoleniom, muszą płynąć z Komisji Europejskiej. Należy jednak mieć nadzieję, że zapadły wyrok Trybunału Sprawiedliwości wymusi na polskich władzach publicznych podjęcie skutecznych działań na rzecz poprawy jakości stanu powietrza i walki z jego zanieczyszczeniem, także po to, by uniknąć niebagatelnych sankcji finansowych.

Polityka zapewniająca bezpieczeństwo ekologiczne jest działaniem długofalowym, a jej wymierne rezultaty są widoczne w dłuższym okresie, około 5-letnim. Jednym z podstawowych narzędzi tej polityki jest stanowienie i stosowanie przepisów dotyczących ochrony środowiska. Przyniosły one Polsce wiele pozytywnych zmian, z korzyścią zarówno dla poszczególnych elementów środowiska, jak i ochrony zdrowia. Należy przyznać, że na przestrzeni kilku ostatnich lat poprawie uległa jakość wody, większość ścieków poddawana jest procesom oczyszczania, uregulowano gospodarkę odpadami, podejmowane są działania na rzecz poprawy jakości powietrza. Zredukowano emisję CO2 (głównie wskutek upadku przemysłu ciężkiego) oraz podjęto działania mające na celu minimalizację emisji szkodliwych gazów i pyłów do powietrza - PM10, PM2,5, benzo(a)pirenu, ozonu, tlenków azotu, dwutlenku siarki. Po długich pracach przyjęto Krajowy Program Ochrony Powietrza (jest to jednakże jedynie dokument planistyczny, który nie gwarantuje zdecydowanych i skutecznych działań), jak i programy ochrony powietrza dla miejsc, w których następowały przekroczenia, a występowały praktycznie w całej Polsce. W 2015 r. uchwalono tzw. ustawę antysmogowąa ${ }^{17}$, dzięki której samorządy mogą, ale nie muszą wprowadzać uchwały antysmogowe ${ }^{18}$, przy czym należy zaznaczyć, iż poszczególne samorządy coraz liczniej podejmują różnorodne proekologiczne aktywności na szczeblu lokalnym. Jednak mimo to, niestety, jakość powietrza w Polsce wciąż pozostaje zła. Walka z zanieczyszczeniem powietrza w Polsce jawi się obecnie jako jeden z kluczowych elementów obowiązku prowadzenia polityki zapewniającej bezpieczeństwo ekologiczne. Musi wyjść z fazy planów i rekomendacji rządowych i skoncentrować się na konkretnych rozwiązaniach władzy publicznej prowadzących do poprawy jakości powietrza

${ }^{17}$ Ustawa z dnia 10 września 2015 r. o zmianie ustawy - Prawo ochrony środowiska (Dz.U. z 2015 r., poz. 1593). Na podstawie znowelizowanego art. 96 ustawy Prawo ochrony środowiska w celu zapobieżenia negatywnemu oddziaływaniu na zdrowie ludzi lub na środowisko sejmik województwa ma uprawnienie do przyjmowania uchwał wprowadzających ograniczenia lub zakazy w zakresie eksploatacji instalacji, w których następuje spalanie paliw (tzw. uchwał antysmogowych).

${ }^{18}$ Celem tychże uchwał jest przeciwdziałanie problemowi niskiej emisji oraz realizacja jednej z kluczowych zasad prawa ochrony środowiska, jaką jest zasada prewencji. Sejmiki województw mogą podejmować uchwały zawierające zakazy i ograniczenia dotyczące np. ogrzewania domów na danym terenie węglem albo jego najgorszymi gatunkami, takimi jak miał, muł, flot węglowy, czy określać parametry techniczne eksploatowanych kotłów. Regulacje antysmogowe, wprowadzające ograniczenia lub zakazy dotyczące eksploatacji kotłów, pieców i kominków, zostały uchwalone jak dotąd przez sejmiki 7 województw: małopolskiego, śląskiego, opolskiego, mazowieckiego, łódzkiego, dolnośląskiego i wielkopolskiego. 
w naszym kraju. Realizacja założeń tej polityki musi przyspieszyć i mieć postać nie tylko konkretnych, ale także zdecydowanych i kompleksowych działań na rzecz poprawy jakości tego elementu środowiska ${ }^{19}$.

\section{BIBLIOGRAFIA}

Banaszak, Bogusław. 2012. Konstytucja Rzeczpospolitej Polskiej. Komentarz. Warszawa: Wydawnictwo C.H. Beck.

Bukowski, Zbigniew. 2002. „Konstytucyjne podstawy obowiązków państwa w zakresie ochrony środowiska". Prawo i Środowisko 4: 63-73.

Bułajewski, Stanisław, Marcin Dąbrowski. 2008. „Wolności i prawa ekonomiczne, socjalne i kulturalne”. W Wolności i prawa człowieka w Konstytucji Rzeczypospolitej Polskiej. Red. Marek Chmaj. 151-192. Warszawa: Wolters Kluwer.

Dziamski, Zbigniew, Waldemar Nowosielski. 2012. „Teoretyczne założenia bezpieczeństwa ”. Prace Naukowe Akademii im. Jana Dtugosza w Czestochowie 7: 201-216.

Garlicki, Lech. Red. 2003. Konstytucja Rzeczypospolitej Polskiej. Komentarz. Warszawa: Wydawnictwo C.H. Beck.

Haładyj, Anna. 2002. „Konstytucyjne prawo do korzystania z wartości środowiska”. Prawo i Środowisko 2: 37-44.

Jakimowicz, Wojciech. 1999. „O publicznych prawach podmiotowych”. Państwo i Prawo 1: 36-50.

Jaworowicz-Rudolf, Agnieszka. 2010. „Prawo do środowiska należytej jakości jako urzeczywistnienie koncepcji zrównoważonego rozwoju”. W Zrównoważony rozwój na poziomie lokalnym i regionalnym. Teoria i praktyka. Red. Małgorzata Burchard-Dziubińska, Agnieszka Rzeńca. 46-80. Łódź: Wydawnictwo Uniwersytetu Łódzkiego.

Jaworowicz-Rudolf, Agnieszka. 2013. „Odpowiedzialność administracji publicznej za stan środowiska”. W Odpowiedzialność administracji $i$ w administracji. Red. Zofia Duniewska, Małgorzata Stahl. 567-575. Warszawa: Wolters Kluwer.

Korzeniowski, Piotr. 2012. Bezpieczeństwo ekologiczne jako instytucja prawna ochrony środowiska. Łódź: Wydawnictwo Uniwersytetu Łódzkiego.

Paczuski, Ryszard. 2005. „Bezpieczeństwo ekologiczne jako kryterium koniecznych działań na rzecz zrównoważonego rozwoju". W Zrównoważony rozwój. Od utopii do praw człowieka. Red. Andrzej Papuziński. 119-132. Bydgoszcz: Oficyna Wydawnicza Branta.

Pietraś, Marek. 2000. Bezpieczeństwo ekologiczne w Europie. Lublin: Wydawnictwo Uniwersytetu Marii Curie-Skłodowskiej.

${ }^{19}$ Stanowczo należy poprzeć postulat przyjęcia odpowiednich norm jakości węgla sprzedawanego do gospodarstw domowych oraz stworzenie systemu świadectw jakości dla tego paliwa. Te regulacje miały zostać wprowadzone już w ubiegłym roku. Odnotować tu należy, że 6 marca 2018 r. Rada Ministrów przyjęła wreszcie dawno zapowiadany Projekt ustawy o zmianie ustawy o systemie monitorowania i kontrolowania jakości paliw oraz ustawy o Krajowej Administracji Skarbowej. Zob. http://legislacja.rcl.gov.pl/projekt/12294812 [dostęp 15.07.2018]. W kwietniu 2018 r. Sejmowa Komisja do spraw Energii i Skarbu Państwa przyjęła ww. projekt w pierwszym czytaniu. Zob. druk nr 2377, http://www.sejm.gov.pl/Sejm8.nsf/druk.xsp?documentId=F651AB E00EC89E4BC12582580034D837 [dostęp 15.07.2018]. Celem projektowanej ustawy jest poprawa jakości powietrza poprzez wyeliminowanie ze sprzedaży - głównie do sektora komunalnego - paliw stałych najgorszej jakości. Wprowadza ona wymagania jakościowe dla paliw stałych oraz umożliwia kontrolowanie ich jakości. 
Raburski, Tomasz. 2017. „Filozofia praw podmiotowych”. Acta Universitatis Lodziensis. Folia Iuridica 78: 55-67.

Rakoczy, Bartosz. 2006. Ograniczanie praw i wolności jednostki ze względu na ochronę środowiska w Konstytucji Rzeczypospolitej Polskiej. Toruń: TNOiK.

Rakoczy, Bartosz. 2007. „Prawo do poszanowania życia prywatnego i rodzinnego a prawo do ochrony środowiska naturalnego". Monitor Prawniczy 22. https://czasopisma.beck.pl/monitor-prawniczy/artykul/prawo-do-poszanowania-zycia-prywatnego-i-rodzinnego-a-prawo-do-ochrony-srodowiska-naturalnego/ [dostęp 15.07.2018].

Surówka, Anna. 2012. „Bezpieczeństwo ekologiczne a gospodarowanie odpadami w świetle prawa konstytucyjnego". Przeglad Prawa Konstytucyjnego 4: 151-167.

Wróblewski, Mirosław. 2015. „Karta Praw Podstawowych Unii Europejskiej w polskim sądownictwie - problemy i wyzwania”. Kwartalnik Krajowej Rady Sadownictwa 2: 17-23.

\section{Inne źródła}

http://www.polskabezsmogu.pl [dostęp 15.07.2018].

https://www.mos.gov.pl/fileadmin/user_upload/mos/Aktualnosci/2018/styczen_2018/Informacja nt._stanu_zaawansowania_prac_nad_rekomendacjami_-_Program_Czyste_Powietrze.pdf [dostęp 15.07.2018].

https://www.pl.clientearth.org/ [dostęp 15.07.2018].

Rekomendacje Komitetu Ekonomicznego Rady Ministrów w sprawie działań niezbędnych do podjęcia w związku z występowaniem na znacznym obszarze kraju wysokiego stężenia zanieczyszczeń powietrza z dnia 25 kwietnia 2017 r. tzw. Program pt. „Czyste powietrze”. https:// www.premier.gov.pl/wydarzenia/decyzje-rzadu/rekomendacje-komitetu-ekonomicznego-rady-ministrow-w-sprawie-dzialan.html [dostęp 15.07.2018].

\section{Akty prawne i materialy legislacyjne}

Dyrektywa Parlamentu Europejskiego i Rady nr 2008/50/WE z dnia 21 maja 2008 r. w sprawie jakości powietrza i czystszego powietrza dla Europy (Dz.Urz. UE L 152 z 11.06.2008, s. 1-44).

Karta Praw Podstawowych Unii Europejskiej (Dz.Urz. UE C 202/389 z 7.06.2016).

Konstytucja Rzeczypospolitej Polskiej z dnia 2 kwietnia 1997 r. (Dz.U. z 1997 r. Nr 78, poz. 483 ze zm.).

Konwencja o Ochronie Praw Człowieka i Podstawowych Wolności z dnia 4 listopada 1950 r. (Dz.U. z 1993 r. Nr 61, poz. 284 ze zm.).

Projekt ustawy o zmianie ustawy o systemie monitorowania i kontrolowania jakości paliw oraz ustawy o Krajowej Administracji Skarbowej. 2017. http://legislacja.rcl.gov.pl/projekt/12294812 [dostęp 15.07.2018].

Rozporządzenie Ministra Rozwoju i Finansów z dnia 1 sierpnia 2017 r. w sprawie kotłów na paliwo stałe (Dz.U. z 2017 r., poz. 1690).

Rządowy projekt ustawy o zmianie ustawy o systemie monitorowania i kontrolowania jakości paliw oraz ustawy o Krajowej Administracji Skarbowej. 2018. Druk nr 2377. http://www.sejm. gov.p1/Sejm8.nsf/druk.xsp?documentId=F651ABE00EC89E4BC12582580034D837 [dostęp 15.07.2018].

Ustawa z dnia 23 kwietnia 1964 r. - Kodeks cywilny (tekst jedn. Dz.U. z 2018 r., poz. 1025 ze zm.). Ustawa z dnia 8 marca 1990 r. o samorządzie gminnym (tekst jedn. Dz.U. z 2019 r., poz. 506).

Ustawa z dnia 24 czerwca 1999 r. o wykonywaniu inicjatywy ustawodawczej przez obywateli (Dz.U. z 1999 r. Nr 62, poz. 688 ze zm.).

Ustawa z dnia 10 września 2015 r. o zmianie ustawy - Prawo ochrony środowiska (Dz.U. z 2015 r., poz. 1593). 


\title{
Orzecznictwo
}

The Supreme Court, R (on the application of ClientEarth) (Appellant) v Secretary of State for the Environment, Food and Rural Affairs (Respondent) - The Supreme Court Judgment date: 29 Apr 2015. Case ID UKSC 2012/0179. https:/www.supremecourt.uk/cases/uksc-2012-0179.html [dostęp 15.07.2018].

Wyrok Sądu Apelacyjnego w Katowicach z dnia 23 stycznia 2014 r., sygn. akt VACa/649/13. https:// www.saos.org.pl/judgments/40027 [dostęp 15.04.2019].

Wyrok Sądu Okręgowego w Gliwicach z dnia 6 czerwca 2013 r., sygn. akt II C 20/13, niepublikowany.

Wyrok Trybunału Konstytucyjnego z dnia 6 czerwca 2006 r., sygn. akt K 23/05, OTK A 2006, nr 6, poz. 62.

Wyrok Trybunału Konstytucyjnego z dnia 13 maja 2009 r., sygn. akt Kp 2/09, OTK ZU, nr 5A/09, poz. 66.

Wyrok Trybunału Sprawiedliwości (trzecia izba) z dnia 5 kwietnia 2017 r. - Komisja Europejska przeciwko Republice Bułgarii (Sprawa C-488/15). http://curia.europa.eu/juris/liste. jsf?num=C-488/15\&language=PL [dostęp 15.07.2018].

Wyrok Wojewódzkiego Sądu Administracyjnego w Gliwicach z dnia 24 listopada 2015 r., sygn. akt I SA/Gl 370/15. http://orzeczenia.nsa.gov.pl/doc/5986875EEA [dostęp 15.07.2018].

\author{
Agnieszka Jaworowicz-Rudolf
}

\section{PUBLIC AUTHORITIES' COMMITMENT TO FOLLOW A POLICY PROVIDING ECOLOGICAL SAFETY UNDERSTOOD AS A SYNONYM OF APPROPRIATE QUALITY OF THE ENVIRONMENT}

\begin{abstract}
The author analyzes issues of the constitutional commitment of public authorities to care for the quality of the environment, taking into account future generations. She indicates that the concept of ecological security has not been specified explicitly by the legislator, and the views formulating the right to ecological safety are considered disputable. It was emphasized that the problem of low emission is currently the key challenge for public authorities.
\end{abstract}

Keywords: environment, protection, security, policy. 